Sains Malaysiana 50(11)(2021): 3313-3320

http://doi.org/10.17576/jsm-2021-5011-15

\title{
MiR-122-5p Attenuates Endothelial-to-Mesenchymal Transition Induced by Oxygen and Glucose Deprivation/Reperfusion
}

(MiR-122-5p Mengatenuasi Peralihan Endotelium-kepada-Mesenkim Teraruh oleh Kekurangan Oksigen dan Glukosa/ Reperfusi)

\author{
HAiYAN Yu, JinQIU Xu, PEngYin ZhU \& ChUnYAN ZHANG*
}

\section{ABSTRACT}

Endothelial-to-mesenchymal transition (EndoMT) is a common phenomenon in vascular diseases, while the role of endothelial dysfunction in central vascular disease remains to be further investigated. MiR-122 is an inflammationassociated non-coding RNA that participates in multiple human disease, but whether miR-122 plays as a critical role in EndoMT induced by ischaemic stroke is unknown. Although BAI2 is known as a brain-specific inhibitor protein of angiogenesis, few studies of BAI2 examined EndoMT. This study investigated the mechanism of EndoMT and the miR-122/BAI2 axis in oxygen-glucose deprivation/reperfusion (OGD/R)-mediated EndoMT. A transient middle cerebral artery occlusion (tMCAO) model and OGD/R treatment were used to mimic the ischaemia-reperfusion injury. The colocalization of CD31 and $\alpha$-SMA was elevated in the peri-infarct area of tMCAO mice. The expression of miR-122 was decreased in the peri-infarct area of tMCAO mice. Downregulation of miR-122, Occludin, and ZO-1 was observed in human brain microvascular endothelial cells (HBMECS) after OGD/R treatment, while $\alpha$-SMA expression was increased in HBMECs after OGD/R treatment. MiR-122 overexpression reduced the decrease of Occludin and ZO-1 expression and the increase of $\alpha$-SMA expression induced by $O G D / R$. MiR-122 negatively regulated BAI2 expression, and OGD/R treatment enhanced BAI2 expression. Knockdown the expression of BAI2 suppressed the decrease of Occludin and ZO-1 expression and the increase of $\alpha$-SMA expression induced by $O G D / R$. In conclusion, miR-122 overexpression attenuates OGD/R-mediated EndoMT by targeting BAI2.

Keywords: BAI2; EndoMT; miR-122; OGD/R

ABSTRAK

Peralihan endotelium-kepada-mesenkim (EndoMT) adalah fenomena biasa untuk penyakit vaskular, manakala peranan disfungsi endotelium pada penyakit vaskular pusat masih perlu dikaji lebih lanjut. MiR-122 ialah RNA bukan pengekodan yang berkaitan dengan keradangan yang menyumbang kepada pelbagai penyakit manusia, tetapi sama ada miR-122 memainkan peranan penting dalam EndoMTyang disebabkan oleh strok iskemia tidak diketahui. Walaupun BAI2 dikenali sebagai protein angiogenesis perencat khusus otak, beberapa kajian BAI2 mengkaji EndoMT. Penyelidikan ini mengkaji mekanisme EndoMT dan paksi miR-122/BAI2 dalam kekurangan oksigen-glukosa/reperfusi (OGD/R)pengantara EndoMT. Model oklusi arteri serebrum tengah sementara (tMCAO) dan rawatan OGD/R digunakan untuk meniru kecederaan reperfusi iskemia. Kolokalisasi CD31 dan $\alpha$-SMA dinaikkan di kawasan peri-infark tikus tMCAO. Pengekspresan miR-122 telah menurun di kawasan peri-infark tikus tMCAO. Pengawalaturan rendah miR-122, Occludin dan ZO-1 diperhatikan dalam sel endotelium mikrovaskular otak manusia (HBMEC) selepas rawatan OGD/R, manakala pengekspresan $\alpha$-SMA meningkat dalam HBMEC selepas rawatan $O G D / R$. Pengekspresan berlebihan MiR-122 mengurangkan penurunan pengekspresan Occludin dan ZO-1 dan peningkatan pengekspresan $\alpha$-SMA yang disebabkan oleh OGD/R. MiR-122 mengawal pengekspresan BAI2 secara negatif dan rawatan OGD/R meningkatkan pengekspresan BAI2. Pengurangan pengekspresan BAI2 menindas penurunan pengekspresan Occludin dan ZO-1 serta peningkatan pengekspresan $\alpha$-SMA yang disebabkan oleh OGD/R. Kesimpulannya, pengekspresan berlebihan miR-122 melemahkan OGD/R-pengantara EndoMT dengan menyasarkan BAI2.

Kata kunci: BAI2; EndoMT; miR-122; OGD/R 


\section{INTRODUCTION}

Ischaemic stroke is one of the most common acute cerebrovascular diseases in modern society and one of the main causes leading to human disability. The incidence of stroke has increased in recent years, which extremely causes nerve function defects and nerve cell necrosis after stroke onset. Currently, the main treatment methods for ischaemic stroke include vascular recanalization operations and thrombolysis drugs (Warner et al. 2019). However, there is still a risk of reperfusion injury, which may further aggravate brain tissue damage or affect the recovery process after ischaemic stroke (Bernstein et al. 2019; Zhang et al. 2019). Growing evidences have shown that the structures and functions of vascular endothelial cells are disrupted after ischaemia-reperfusion injury, and this disruption is accompanied by endothelial-tomesenchymal transition (EndoMT) and inflammatory responses (Bernstein 2019; Tan et al. 2019). Reconstruction of endothelial structures and functions promotes the recovery of ischaemic stroke in animal models, secondarily suppressing inflammation (Brait et al. 2019; Wang et al. 2018). Though EndoMT seems to play a critical role in ischaemic stroke, the mechanism of EndoMT in ischaemic stroke is still not fully understood. Thus, molecules participating in the regulation of inflammation induced by vascular recanalization may possess the ability to protect endothelial structures and functions by restraining EndoMT.

MicroRNAs (miRNAs) are a type of non-coding RNA molecule and widely involved in the growth, development and diseases in mammals (Mohr \& Mott 2015). Studies have shown that the expression of miRNAs in the brain significantly changes after stroke, suggesting that miRNAs may play an important role in the neurological impairment and vascular injury induced by stroke (Liu et al. 2015). MicroRNA-122-5p (miR-122) has been reported that it is closely associated with an inflammatory reactions in peripheral and central diseases (Li et al. 2017; Lv et al. 2018). However, it is still unclear that whether miR-122 is participated in EndoMT induced by ischemia-reperfusion injury. Here, oxygen-glucose deprivation/reperfusion (OGD/R) was applied to establish an in vitro EndoMT model simulating the endothelial injury and inflammatory reactions after ischemic stroke. Our study investigated the role of miR-122/BAI2 in EndoMT induced by oxygen-glucose deprivation/ reperfusion (OGD/R) and identified a potential drug target for vasculopathy after ischemia-reperfusion.

\section{MATERIALS AND Methods}

Human brain microvascular endothelial cells (HBMECs) were purchased from Jennio Biotech company and cultured in DMEM/F-12 (11320082, Gibco) containing $10 \%$ foetal bovine serum (FBS, 10099133, Gibco) and $1 \%$ streptomycin/penicillin $(15140122$, Gibco) in a $5 \%$ $\mathrm{CO}_{2}$ and $95 \%$ air incubator at $37^{\circ} \mathrm{C}$.

\section{TRANSIENT MIDDLE CEREBRAL ARTERY OCCLUSION (TMCAO)}

Adult male mice (C57BL/6, 8-week old) were purchased from the Laboratory Animal Center of Nantong University. Mice were sedated with $1 \%$ pentobarbital sodium. The right external carotid artery was blocked from the internal carotid artery to the middle cerebral artery by a siliconecoated nylon filament. After artery occlusion for $1 \mathrm{~h}$, mice were narcosed and the nylon filament was removed from artery. For sham group mice, external carotid artery was twisted, while the internal carotid artery was not occluded. After reperfusion for $6 \mathrm{~h}$, all mice were sacrificed by an overdose of pentobarbital sodium and subjected to heart perfusion with normal saline to remove blood from the vessels. The peri-infarct areas were removed from the ischaemic cortex after uncovering the skull. For sham group mice, the corresponding areas were removed from the cortex. This work was sanctioned by the Animal Use and Care Committee of Nantong University.

\section{$\mathrm{OGD} / \mathrm{R}$}

HBMECs were plated in culture dishes with medium containing $10 \% \mathrm{FBS}$ and $1 \%$ streptomycin/penicillin. HBMECs of control group did not receive any treatment. The medium of HBMECs in the OGD/R group was exchanged with medium without glucose, and the HBMECs of OGD/R group were cultured in a hypoxic condition $\left(1 \% \mathrm{O}_{2}, 5 \% \mathrm{CO}_{2}\right.$ and $\left.94 \% \mathrm{~N}_{2}\right)$ for $3 \mathrm{~h}$. After oxygen-glucose deprivation, culture medium was replaced with normal medium containing $10 \%$ FBS and $1 \%$ streptomycin/penicillin, and culture condition was changed to a normal condition ( $1 \%$ air and $\left.5 \% \mathrm{CO}_{2}\right)$.

\section{MIR-122 LENTIVIRUS AND BAI2 SIRNA TRANSFECTION}

HBMECs were plated in cell dishes with serumfree culture medium and lentivirus purchased from HanBio Company was blent into serum-free medium accompanying with polybrene $(\mathrm{MOI}=3)$. After $24 \mathrm{~h}$, serum-free medium was replaced with normal medium and $\mathrm{OGD} / \mathrm{R}$ treatment was subsequently performed. For BAI2 siRNA transfection (GenePharma), HBMECs of $2 \times 10^{5}$ were transfected with $0.1 \mu \mathrm{M}$ siRNA and 1 
$\mu \mathrm{L}$ transfection reagent from Santa Cruz (sc-29528) in serum-free medium for $24 \mathrm{~h}$. Serum-free medium was replaced with normal medium and $\mathrm{OGD} / \mathrm{R}$ treatment was subsequently performed. The sequence of BAI2 siRNA was 5'-CCUGGAGCGAAAGAAAUUATT-3'.

\section{REAL-TIME PCR}

Total RNA was extracted from HBMECs in Trizol solution (T9108, Takara) and reverse transcribed into cDNA with HiScript Q RT SuperMix for qPCR solution (R122, Vazyme). MiR-122 and BAI2 mRNA expression were detected with qPCR SYBR Green Master Mix purchased from Vazyme (Q121). MiR-122 primers: forward primer (5'-GGGCTGGAGAGAGACAAT-3'); reverse primer (5'-GAATACCTCGGACCCTGC-3'). U6 primers: forward primer (5'-GGTCGGGCAGGAAAGAGGGC-3'); reverse primer (5'-GCTAATCTTCTCTGTATCGTTCC-3'). BAI 2 mRNA primers: forward primer (5'-CCGCCTTAGGGATGGCAAAC-3'); reverse primer (5'-ACAGTAAGAGGGGACAGGCT-3'). $\beta$-actin mRNA primers: forward primer (5' ACCCCGTGCTGCTGACCGAG-3'); reverse primer (5'TCCCGGCCAGCCAGGTCCA-3').

\section{LUCIFERASE ASSAY}

HBMECs were transfected with pMIR-REPORT luciferase plasmid (RiboBio, Guangzhou,) containing a wild-type or mutated 3'-untranslated region (UTR) of BAI2 mRNA in 96-well plates for $48 \mathrm{~h}$. Luciferase assay was performed according to the manufacturer's instruction (E2920, Promega). Renilla luciferase signal was normalized to firefly luciferase signal, and numerical values were calculated as a relative proportion of the wildtype plasmid.

\section{WESTERN BLOT}

Western blot was performed as previously described. Briefly, HBMECs were lysed with RIPA lysis buffer (P0013C, Beyotime) and protein concentration was tested by BCA protein assay kit (P0012S, Beyotime). Polyacrylamide gel electrophoresis was used to separate proteins of different sizes and proteins were transferred to polyvinylidene fluoride membranes (IPVH00010, Millipore). Membrane was incubated with primary antibody overnight, and subsequently incubated with second antibody labelled with horse radish peroxidase. Target proteins were visualized using a Tanon chemiluminescence system. Band intensity was quantified using ImageJ software. Protein relative levels were shown as fold change relative to control group. Primary antibodies were listed as followed: Occuludin (33-1500, Invitrogen), ZO-1(40-2300, Thermo Fisher Scientific), $\alpha$-SMA (14395-1-AP, Proteintech), BAI2 (ab189112, Abcam) and $\beta$-actin (60008-1-Ig, Proteintech).

\section{STATISTICAL ANALYSIS}

All experimental data were expressed as the mean \pm SD from three independent experiments. Statistical analysis was performed using GraphPad Prism 6.0 and significance was assessed using Student's t test for comparisons of 2 groups or two-way ANOVA followed by Bonferroni's post hoc multiple comparison tests for comparisons of 3 or more groups. Results were considered significant at $P<0.05$.

\section{RESULTS AND DISCUSSION}

\section{OGD/R TREATMENT INDUCED ENDOMT}

As shown in Figure 1(A), elevated colocalization of CD3 1 and $\alpha$-SMA was observed in the peri-infarct area of tMCAO mice by fluorescence microscopy. To investigate the endothelial injury induced by ischaemic reperfusion, OGD/R treatment was performed to mimic the endothelial injury in vitro. Next, the expression of endothelial cell tight junction proteins (Occludin and ZO-1) was examined by western blot. As shown in Figure 1(B)-1(D), Occludin and ZO-1 expression were decreased in a time-dependent manner after $\mathrm{OGD} / \mathrm{R}$ compared to the control group. There was a time-dependent increase in $\alpha$-SMA expression after OGD/R treatment and $\alpha$-SMA reached a valley value at $12 \mathrm{~h}$ in Figure 1(E)-1(F).

\section{MIR-122 OVEREXPRESSION SUPPRESSED OGD/R- INDUCED ENDOMT}

Expression of miR-122 was significantly declining in the peri-infarct area of tMCAO mice (Figure 2(A)). To explore the effect of miR-122 on HBMECs during the OGD/R treatment process, we next examined the expression of miR-122 after OGD/R. As shown in Figure 2(B), miR-122 expression was decreased in a time-dependent manner in OGD/R group compared with the control group and reached a valley value at $12 \mathrm{~h}$. Thus, HBMECs were pretreated with miR-122 lentivirus to observe the effect of miR-122 expression on the EndoMT induced by OGD/R. MiR-122 overexpression significantly rescued the reduction of tight junction proteins, Occludin and ZO-1, mediated by OGD/R in Figure 2(C)-2(E). Moreover, miR-122 overexpression also notably inhibited the 
enhanced expression of $\alpha$-SMA after OGD/R in Figure $2(\mathrm{C})$ and $2(\mathrm{~F})$. These results verified that miR-122 was involved in the OGD/R-mediated EndoMT.

\section{MIR-122 NEGATIVELY REGULATED BAI2}

To discover the downstream targets of miR-122 in the EndoMT process, we predicted the target mRNAs by TargetScan (http://www.targetscan.org/vert_72/). As shown in Figure 3(A), there was a miR-122 binding site in 3'-UTR of BAI2 mRNA, which indicated that miR-122 may play a potential role in the regulation of BAI2 at the post-transcriptional level. To confirm this hypothesis, a luciferase reporter assay was performed and transfection of the luciferase reporter plasmid with BAI2 mRNA 3'-UTR resulted in the hypoactive luciferase activity (Figure 3(B)). The expression of BAI2 was increased in a time-dependent manner in the $\mathrm{OGD} / \mathrm{R}$ group compared with the control group (Figure 3(C)3(D)). Transfection of miR-122 lentivirus into HBMECs restrained the expression of BAI2, and transfection of anti-miR-122 lentivirus heightened the expression of BAI2 on the contrary (Figure 3(E)-3(F)). These results illustrated that miR-122 repressed BAI2 expression at the post-transcriptional level.

\section{BAI2 KNOCKDOWN INHIBITED OGD/R-INDUCED ENDOMT}

Having determined the effect of miR-122 on BAI2, we further explored the role of BAI2 in the OGD/R-induced EndoMT. BAI2 siRNA was transfected into HBMECs and interference efficiency was confirmed by western blot. BAI2 siRNA notably weakened the expression of BAI2 (Figure 4(A)-4(B)). BAI2 siRNA significantly rescued the reduction of tight junction proteins, Occludin and ZO-1, induced by OGD/R in Figure 4(C)-4(E)). Moreover, BAI2 siRNA also inhibited the enhanced expression of $\alpha$-SMA after OGD/R in Figure 4(C) and 4(F). These results verified that BAI2 was involved in the OGD/R-mediated EndoMT.

\section{DISCUSSION}

As a highly disabling and lethal disease, ischaemic stroke has received a great deal of attention from the scientific community. The existing treatment strategies pay giant attention on reperfusion of blood vessels, while reperfusion injury characterized as EndoMT has been overlooked. The elevated colocalization of CD31, an endothelial cell marker, and $\alpha$-SMA, a mesenchymal cell marker, in the peri-infarct area of tMCAO mice suggested that endothelial cells gradually obtained characteristics of mesenchymal cells. The experiment in HBMECs subjected to OGD/R treatment demonstrated that HBMECs gradually acquired mesenchymal characteristics. These results demonstrated that OGD/R treatment could induce EndoMT consistent with tMCAO model. Past researches have shown that miRNAs are extensively involved in the occurrence and development of human diseases ( $\mathrm{Li}$ et al. 2018; Miao et al. 2018), including ischemic stroke (Hamzei Taj et al. 2016; Vijayan et al. 2019). There was a strong correlation between the expression of miR-9 and miR-124 in the peripheral blood and stroke condition, indicating that miRNAs potentially have key roles in neuroinflammatory and vascular destruction after stroke (Liu et al. 2015; Li et al. 2017; Sorensen et al. 2017). Recently, studies have highlighted the link between miR-122 and ischaemic stroke (Lv et al. 2018; Stanzione et al. 2017). Given all these evidence, it is possible that miR-122 protects the endothelial cell function during ischaemic injury. In our study, miR-122 expression in HBMECs was decreased significantly after OGD/R treatment, and overexpression of miR-122 restored the function and structure of HBMECs via downregulation of BAI2 expression. The pathomechanism of the EndoMT process was blamed for the involvement of miR-122 and BAI2.

Previous studies on stroke have shown that central nervous system is exposed to an abnormal environment and the structural integrity of blood vessels suffers destroy (Bernstein 2019; Chen et al. 2019). In our study, HBMECs were treated with $\mathrm{OGD} / \mathrm{R}$ and tight junction protein expression was decreased after OGD/R treatment. Having determined the efficacy of the OGD/R model, miR-122 expression was observed a reductive trend in HBMECs with OGD/R treatment. Detection of changes in miR-122 expression in endothelial cells after $\mathrm{OGD} / \mathrm{R}$ treatment further confirmed that miR-122 level was decreased after ischaemia reperfusion ( $\mathrm{Li}$ et al. 2018). Growing evidence has shown that miR-122 level was negatively associated with stroke conditions ( $\mathrm{Li}$ et al. 2018) and blood vessel conditions in diabetes (Pastukh et al. 2019). However, the role of miR-122 in endothelial cells after ischaemia reperfusion still remains unclear. In our study, miR-122 overexpression promoted the cell survival and restoration of tight junction protein expression after $\mathrm{OGD} / \mathrm{R}$ treatment, proving the beneficial effect of miR-122 on function and structure reconstruction of endothelial cells. However, the effect of miR-122 on EndoMT in the tissues around the infarct areas needs to be verified in vivo. 
BAI2 is a type of brain-specific angiogenesis inhibitor and correlated with revascularization induced by stroke (Kee et al. 2002). The expression of BAI2 was increased in a time-dependent manner and reached a peak value at $6 \mathrm{~h}$ after OGD/R treatment. However, the expression of miR-122 reached a minimum value at $12 \mathrm{~h}$, which implied that it is possible for BAI2 to be regulated in another way. A physiological compensatory mechanism may theoretically explain the difference in the timing of the lowest and highest expression of miR122 and BAI2. BAI2 regulated VEGF expression through the transcriptional repressor GABP, which possibly resulted in vascular function recovery (Jeong et al. 2006).
These studies provide strong supporting evidence for our result that BAI2 was negatively involved in regulation of EndoMT after OGD/R treatment. Our study showed that miR-122 negatively regulated the expression of BAI2 at the post-transcriptional level, which filled the gap in downstream mechanism of miR-122 in OGD/Rinduced vascular injury. However, we cannot rule out the possibility that other target genes of miR-122 are also involved in OGD/R-induced EndoMT. In summary, our study indicates that miR-122 protects against OGD/Rmediated EndoMT via BAI 2 and provides a new potential target for treating vascular injury.
A

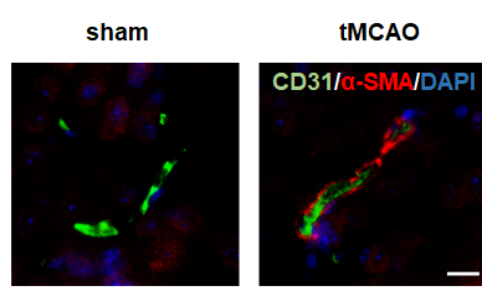

D

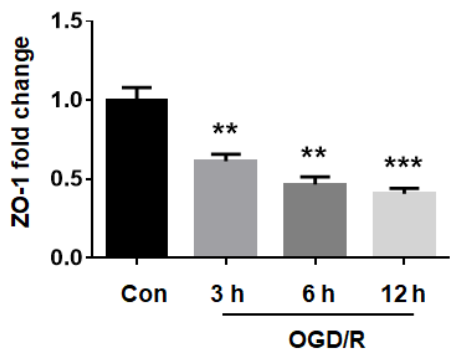

B

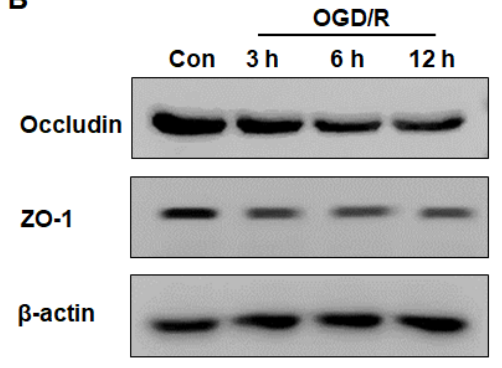

E

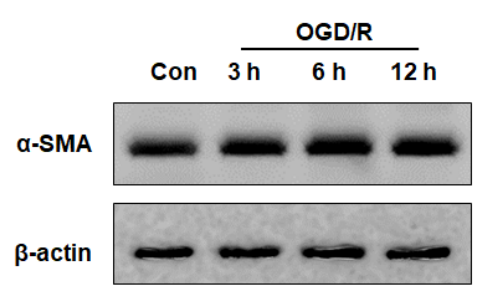

C

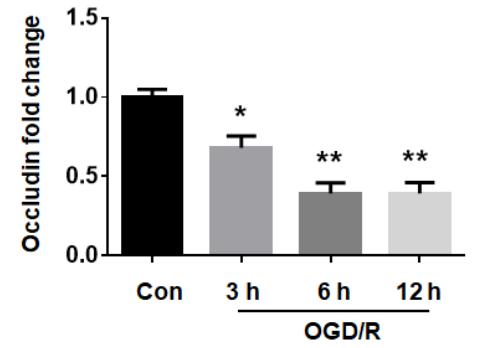

$\mathbf{F}$

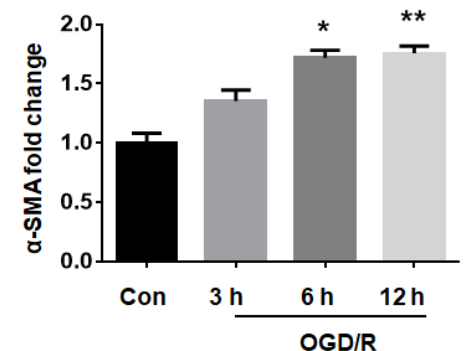

FIGURE 1. OGD/R treatment induced HBMEC injury. (A) Immunofluorescence of CD31 and $\alpha$-SMA in the matched area of sham mice and peri-infarct area of tMCAO mice. Scar bar: $50 \mu \mathrm{m}$, (B) Effect of OGD/R on the expression of Occludin and ZO-1. HBMECs underwent OGD/R treatment for $3 \mathrm{~h}, 6 \mathrm{~h}$, and $12 \mathrm{~h}$ and endothelial cell tight junction proteins were detected by western blot. $\beta$-actin was used as a control for normalization, (C) Quantification of Occludin expression in HBMECs after OGD/R treatment, (D) Quantification of ZO-1 expression in HBMECs after OGD/R treatment, (E) Effect of OGD/R on $\alpha$-SMA expression. HBMECs were underwent OGD/R treatment for $3 \mathrm{~h}, 6 \mathrm{~h}$ and $12 \mathrm{~h}$ and $\alpha$-SMA was detected by western blot. $\beta$-actin was used as a control for normalization, and $(F)$ Quantification of $\alpha$-SMA expression in HBMECs after OGD/R treatment. ${ }^{*} P<0.05,{ }^{* *} P<0.01$ and ${ }^{* * *} P<0.001$ versus the control group. Con: control 


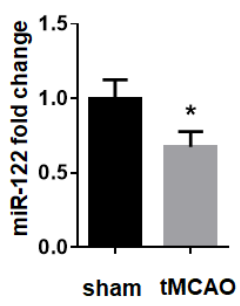

D

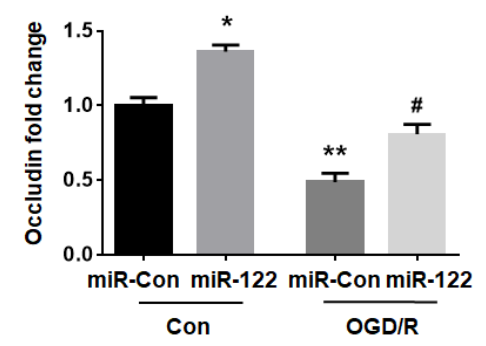

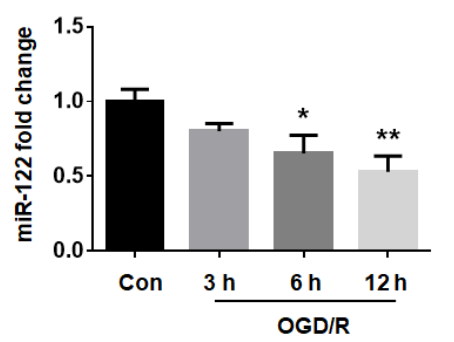

E

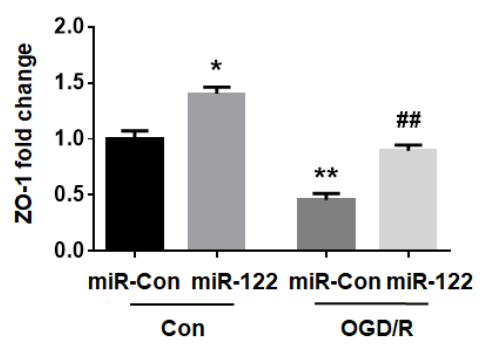

C

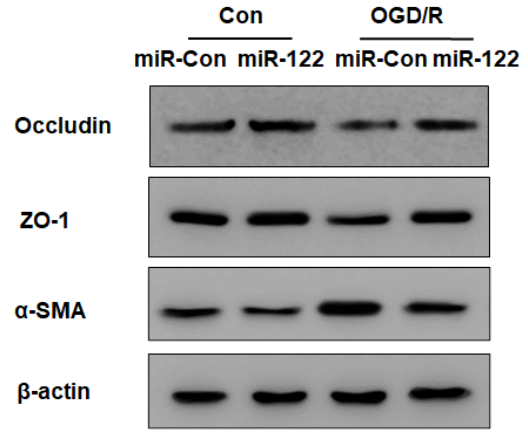

$\mathbf{F}$

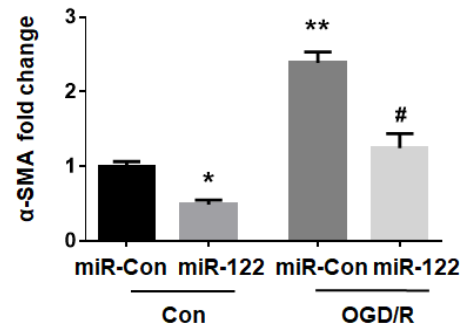

FIGURE 2. MiR-122 protected HBMECs from EndoMT induced by OGD/R. (A) Effect of tMCAO on miR122 expression. ${ }^{*} P<0.05$ versus the sham group, (B) Effect of OGD/R on miR-122 expression. HBMECs were underwent OGD/R treatment for $3 \mathrm{~h}, 6 \mathrm{~h}$ and $12 \mathrm{~h}$ and miR-122 expression was detected by real-time PCR. ${ }^{*} P<0.05$ and ${ }^{* *} P<0.01$ versus the control group, (C) Role of miR-122 in OGD/R-induced EndoMT. HBMECs were transfected with miR-122 lentivirus and subjected to OGD/R treatment for $12 \mathrm{~h}$. Expression of tight junction proteins and $\alpha$-SMA was detected by western blot, (D) Quantification of Occludin expression in HBMECs treated with miR-122 lentivirus before OGD/R, (E) Quantification of ZO-1 expression in HBMECs treated with miR-122 lentivirus before OGD/R, and (F) Quantification of $\alpha$-SMA expression in HBMECs treated with miR-122 lentivirus before OGD/R. ${ }^{*} P<0.05$ and ${ }^{* *} P<0.01$ versus the control miR-control group;

${ }^{\#} P<0.05$ and ${ }^{\# \#} P<0.01$ versus the OGD/R miR-control group. Con: control

A

Position 53-60 of BAI2 3' UTR $\quad 5, \quad \ldots$ UAUCUCUCUAUUUUCACACUCCA... miR-122-5p $33^{\prime} \quad$ GUUUGUGGUAACAGUGUGAGGU

mutantBAI2 3'UTR 5 , ... UAUCUCUCUAUUUUCAGAGUGGA...

D

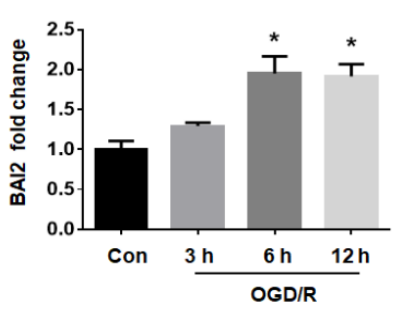

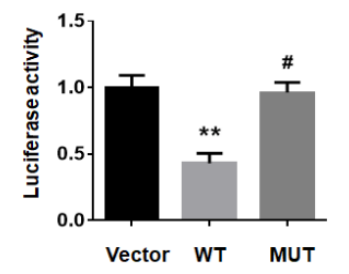

c

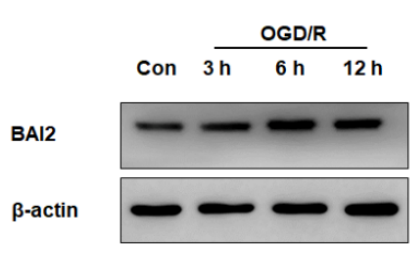

$\mathbf{F}$

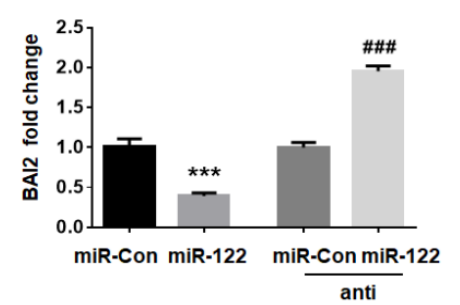

FIGURE 3. BAI2 was the target gene of miR-122. (A) Possible interaction sites between miR-122 and the BAI2 mRNA 3'-UTR predicted by TargetScan, (B) Binding of miR-122 to the BAI2 mRNA 3'-UTR was determined via luciferase assay. Luciferase reporter plasmids with the wild-type or mutated 3'-UTR of BAI2 mRNA were transfected into HBMECs in the presence of the miR-122 lentivirus. ${ }^{* *} P<0.01$ versus vector group; ${ }^{\sharp} P<0.05$ versus wild-type group, (C) Effect of OGD/R on BAI2 expression. HBMECs were underwent OGD/R treatment for $3 \mathrm{~h}, 6 \mathrm{~h}$ and $12 \mathrm{~h}$ and BAI2 expression was detected by western blot. $\beta$-actin was used as a control for normalization, (D) Quantification of BAI2 expression in HBMECs after OGD/R treatment. ${ }^{*} P<0.05$ versus the control group. (E) BAI2 expression was evaluated in HBMECs transduced with miR-122 and anti-miR-122 lentivirus by western blot, and (F) Quantification of BAI2 expression in HBMECs with miR-122 and anti-miR-122 lentivirus treatment. ${ }^{* * *} P<0.001$ versus the miR-control group; ${ }^{\# \#} P<0.001$ versus anti-miR-control group. Con: control; WT: wild type; MUT: mutation 
A

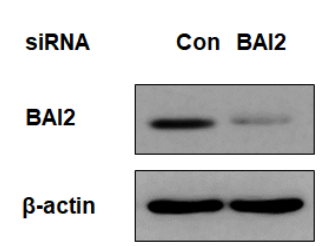

D

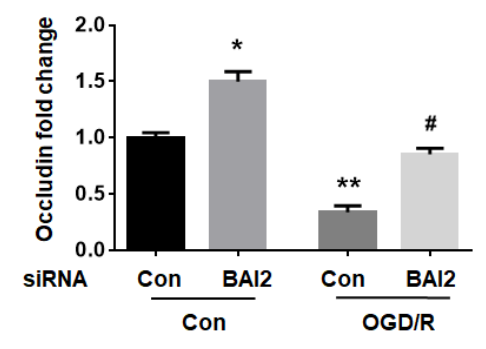

B

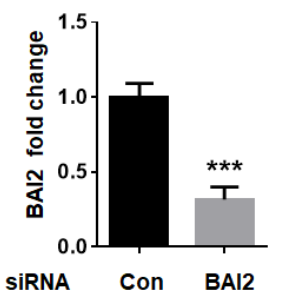

E

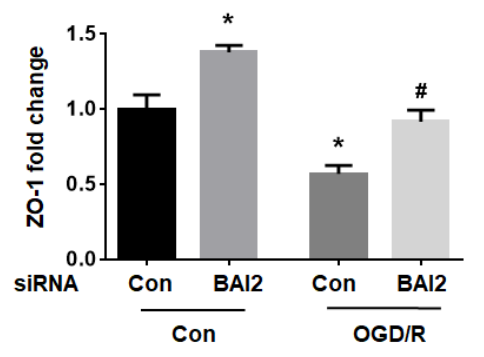

C

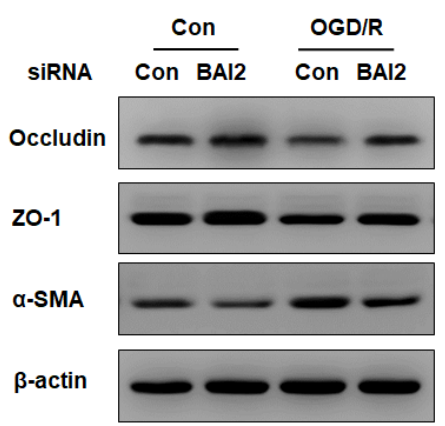

$\mathbf{F}$

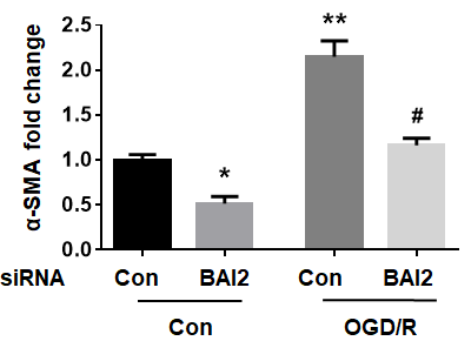

FIGURE 4. Knockdown of BAI2 protected HBMECs from EndoMT induced by OGD/R. (A) Effect of BAI2 siRNA on the expression of BAI2. HBMECs were transfected with BAI siRNA for $24 \mathrm{~h}$ and the efficacy of BAI2 siRNA was determined by western blot, (B) Quantification of BAI2 expression in HBMECs treated with BAI2 siRNA. ${ }^{* * *} P<0.001$ versus the control-siRNA group, (C) Role of BAI2 in OGD/R-induced EndoMT. HBMECs were transfected with BAI2 siRNA and subjected to $\mathrm{OGD} / \mathrm{R}$ treatment for $12 \mathrm{~h}$. The expressions levels of tight junction proteins and $\alpha$-SMA were detected by western blot, (D) Quantification of Occludin expression in HBMECs treated with miR-122 lentivirus before OGD/R, (E) Quantification of ZO-1 expression in HBMECs treated with BAI2 siRNA before OGD/R, and (F) Quantification of $\alpha$-SMA expression in HBMECs with BAI2 siRNA treatment after OGD/R. ${ }^{*} P<0.05$ and ${ }^{* *} P<0.01$ versus the control control-siRNA group; ${ }^{\#} \mathrm{P}<0.05$ versus $\mathrm{OGD} / \mathrm{R}$ the control-siRNA group. Con: control

\section{CONCLUSION}

In summary, we provide evidence indicating that the miR-122/BAI2 axis is involved in OGD/R-induced EndoMT. Overexpression of miR-122 induced the decrease of BAI2 and repressed the EndoMT in vitro. The protective effect of miR-122 in ischaemic stroke may be associated with the restoration of vascular function, which implies a promising strategy for ischaemic stroke treatment.

\section{ACKNOWLEDGEMENTS}

The authors would like to acknowledge their sources of financial support. This work was supported by the Science and Technology Project of Nantong City (grant numbers: JCZ18097) and the Jiangsu Pharmaceutical Association Hospital Pharmaceutical Research Project of Tianqing (grant numbers: Q2019162). All authors declare that they have no conflicts of interest.

\section{REFERENCES}

Bernstein, D.L., Zuluaga-Ramirez, V., Gajghate, S., Reichenbach, N.L., Polyak, B., Persidsky, Y. \& Rom, S. 2019. miR-98 reduces endothelial dysfunction by protecting blood-brain barrier (BBB) and improves neurological outcomes in mouse ischemia/reperfusion stroke model. Journal of Cerebral Blood Flow and Metabolism: Official Journal of the International Society of Cerebral Blood Flow and Metabolism. 271678X19882264.

Brait, V.H., Miro-Mur, F., Perez-de-Puig, I., Notario, L., Hurtado, B., Pedragosa, J., Gallizioli, M., Jimenez-Altayo, F., ArbaizarRovirosa, M., Otxoa-de-Amezaga, A., Monteagudo, J., Ferrer-Ferrer, M., de la Rosa, X., Bonfill-Teixidor, E., SalasPerdomo, A., Hernandez-Vidal, A., Garcia-de-Frutos, P., Lauzurica, P. \& Planas, A.M. 2019. CD69 plays a beneficial role in ischemic stroke by dampening endothelial activation. Circulation Research 124(2): 279-291.

Chen, A.Q., Fang, Z., Chen, X.L., Yang, S., Zhou, Y.F., Mao, L., Xia, Y.P., Jin, H.J., Li, Y.N., You, M.F., Wang, X.X., Lei, H., He, Q.W. \& Hu, B. 2019. Microglia-derived TNF- 
alpha mediates endothelial necroptosis aggravating blood brain-barrier disruption after ischemic stroke. Cell Death \& Disease 10(7): 487.

Hamzei Taj, S., Kho, W., Riou, A., Wiedermann, D. \& Hoehn, M. 2016. MiRNA-124 induces neuroprotection and functional improvement after focal cerebral ischemia. Biomaterials 91: 151-165.

Jeong, B.C., Kim, M.Y., Lee, J.H., Kee, H.J., Kho, D.H., Han, K.E., Qian, Y.R., Kim, J.K. \& Kim, K.K. 2006. Brain-specific angiogenesis inhibitor 2 regulates VEGF through GABP that acts as a transcriptional repressor. FEBS Letters 580(2): 669-676.

Kee, H.J., Koh, J.T., Kim, M.Y., Ahn, K.Y., Kim, J.K., Bae, C.S., Park, S.S. \& Kim, K.K. 2002. Expression of brainspecific angiogenesis inhibitor 2 (BAI2) in normal and ischemic brain: Involvement of BAI2 in the ischemia-induced brain angiogenesis. Journal of Cerebral Blood Flow and Metabolism: Official Journal of the International Society of Cerebral Blood Flow and Metabolism 22(9): 1054-1067.

Li, D.B., Liu, J.L., Wang, W., Luo, X.M., Zhou, X., Li, J.P., Cao, X.L., Long, J.G., Chen, X.H. \& Qin, C. 2018. Plasma exosomal miRNA-122-5p and miR-300-3p as potential markers for transient ischaemic attack in rats. Frontiers in Aging Neuroscience 10: 24.

Li, M., Tang, Y., Wu, L., Mo, F., Wang, X., Li, H., Qi, R., Zhang, H., Srivastava, A. \& Ling, C. 2017. The hepatocytespecific HNF4alpha/miR-122 pathway contributes to iron overload-mediated hepatic inflammation. Blood 130(8): 1041-1051.

Li, W.A., Efendizade, A. \& Ding, Y. 2017. The role of microRNA in neuronal inflammation and survival in the post ischemic brain: A review. Neurological Research. pp. 1-9.

Li, X., Wei, Y. \& Wang, Z. 2018. microRNA-21 and hypertension. Hypertension Research 41(9): 649-661.

Liu, C., Zhao, L., Han, S., Li, J. \& Li, D. 2015. Identification and functional analysis of microRNAs in mice following focal cerebral ischemia injury. International Journal of Molecular Sciences 16(10): 24302-24318.

Liu, Y., Zhang, J., Han, R., Liu, H., Sun, D. \& Liu, X. 2015. Downregulation of serum brain specific microRNA is associated with inflammation and infarct volume in acute ischemic stroke. Journal of Clinical Neuroscience: Official Journal of the Neurosurgical Society of Australasia 22(2): 291-295.

Lv, B., Cheng, X., Sharp, F.R., Ander, B.P. \& Liu, D.Z. 2018. MicroRNA-122 mimic improves stroke outcomes and indirectly inhibits $\mathrm{NOS}_{2}$ after middle cerebral artery occlusion in rats. Frontiers in Neuroscience 12: 767.

Miao, C., Xiong, Y., Zhang, G. \& Chang, J. 2018. MicroRNAs in idiopathic pulmonary fibrosis, new research progress and their pathophysiological implication. Experimental Lung Research 44(3): 178-190.

Mohr, A.M. \& Mott, J.L. 2015. Overview of microRNA biology. Seminars in Liver Disease. 35(1): 3-11.

Pastukh, N., Meerson, A., Kalish, D., Jabaly, H. \& Blum, A. 2019. Serum miR-122 levels correlate with diabetic retinopathy. Clinical and Experimental Medicine 19(2): 255-260.
Sorensen, S.S., Nygaard, A.B., Carlsen, A.L., Heegaard, N.H.H., Bak, M. \& Christensen, T. 2017. Elevation of brain-enriched miRNAs in cerebrospinal fluid of patients with acute ischemic stroke. Biomarker Research 5: 24.

Stanzione, R., Bianchi, F., Cotugno, M., Marchitti, S., Forte, M., Busceti, C., Ryskalin, L., Fornai, F., Volpe, M. \& Rubattu, S. 2017. A decrease of brain microRNA-122 level is an early marker of cerebrovascular disease in the stroke-prone spontaneously hypertensive rat. Oxidative Medicine and Cellular Longevity 2017: 1206420.

Tan, S., Shan, Y., Lin, Y., Liao, S., Zhang, B., Zeng, Q., Wang, Y., Deng, Z., Chen, C., Hu, X., Peng, L., Qiu, W. \& Lu, Z. 2019. Neutralization of interleukin-9 ameliorates experimental stroke by repairing the blood-brain barrier via down-regulation of astrocyte-derived vascular endothelial growth factor-A. FASEB Journal: Official Publication of the Federation of American Societies for Experimental Biology 33(3): 4376-4387.

Vijayan, M., Alamri, F.F., Al Shoyaib, A., Karamyan, V.T. \& Reddy, P.H. 2019. Novel miRNA PC-5P-12969 in ischemic stroke. Molecular Neurobiology 56(10): 6976-6985.

Wang, H.J., Wei, J.Y., Liu, D.X., Zhuang, S.F., Li, Y., Liu, H., Ban, M., Fang, W.G., Cao, L., Zhao, W.D. \& Chen, Y.H. 2018. Endothelial Atg7 deficiency ameliorates acute cerebral injury induced by ischemia/reperfusion. Frontiers in Neurology 9: 998.

Warner, J.J., Harrington, R.A., Sacco, R.L. \& Elkind, M.S.V. 2019. Guidelines for the early management of patients with acute ischemic stroke: 2019 Update to the 2018 guidelines for the early management of acute ischemic stroke. Stroke 50(12): 3331-3332. doi. 10.1161/STROKEAHA.119.027708.

Zhang, Y.P., Cui, Q.Y., Zhang, T.M., Yi, Y., Nie, J.J., Xie, G.H. \& Wu, J.H. 2019. Chloroquine pretreatment attenuates ischemia-reperfusion injury in the brain of ob/ob diabetic mice as well as wildtype mice. Brain Research 146518.

Haiyan Yu

Intensive Care Unit

Shanghai Quyang Hospital, Shanghai

China

Jinqiu Xu \& Chunyan Zhang*

Department of Pharmacy

Affiliated Hospital of Nantong University, Nantong

China

Pengyin Zhu

Department of Pharmacy

Affiliated Hai'an Peoples' Hospital of Nantong University, Nantong

China

*Corresponding author; email: ccyyzhangntfy@163.com

Received: 11 January 2021

Accepted: 11 March 2021 